DOI:10.17951/h.2020.54.4.7-18

\begin{tabular}{lcc}
\hline \multicolumn{4}{c}{ A N N A L E S } \\
UNIVERSITATIS MARIAE CURIE-SKŁODOWSKA \\
LUBLIN - POLONIA \\
SOL. LIV, 4 \\
\hline
\end{tabular}

\author{
MARCIN BĘDZIESZAK \\ marcin.bedzieszak@sgh.waw.pl \\ Warsaw School of Economics. Collegium of Management and Finance \\ 162 Niepodległości Av., 02-554 Warsaw, Poland \\ ORCID ID: https://orcid.org/0000-0003-3167-6356
}

\title{
Is There a Link between User Charges and Expenditures on Public Kindergartens in Poland?
}

Keywords: fees; user charges; local budgets; tax and non-tax revenues

JEL: H20; H27; H71

How to quote this paper: Będzieszak, M. (2020). Is There a Link between User Charges and Expenditures on Public Kindergartens in Poland? Annales Universitatis Mariae Curie-Skłodowska, sectio H-Oeconomia, Vol. 54, No. 4.

\footnotetext{
Abstract

The aim of this article is to assess the link between user charges and expenditures on the service on the example of public kindergartens in Poland. The rationale behind the paper is that implementation of user charges for public service results in efficient use of resources and leads to the passing-on of expenditure increase to consumers. To achieve the aim, three methods were used, namely weighed-least-squares, fixed effect and random effect method. The empirical analysis based on a panel data set for 65 large Polish cities in the years 2012-2018 showed that about $10-25 \%$ of an expenditure increase is passed on to consumers in terms of higher user charge. Moreover, user charge financing has a significant negative effect on the unit cost. An increase in the share of user charges in expenditures by $10 \mathrm{pp}$ causes a decrease in expenditure at the level of $2.5-5.0 \%$.
} 


\section{Introduction}

User charges are often used by public sector entities, not only because they provide additional revenues, but they can also lead to other consequences, e.g. limitation of an excessive use of public services when they are free of charge. Such charges are more often associated with public services of a technical or municipal rather than social nature, which does not mean, however, that in the latter case user charges are not used at all. The Polish local government uses user charges for social services, among others, in the case of kindergartens and social welfare homes. The amount of user charges is usually set at a level which results in revenues as a complementary rather than dominant source of financing for specific service. It does not change the fact that the direct payment is different in nature from the lack of payment.

The aim of this article is to point out the link between user charges and expenditures on a service. The research will be done on an example of kindergarten funding in large Polish cities, due to the fact that in this case charges are collected in two different funds, and additionally cities receive grants for funding education. The latter was introduced during the study period, which allows further investigation on its effect on the amount of user charges and expenditures.

When public sector institutions seek for revenues, and changes (increases) of taxes due to the economic impact and political factors are not possible, they try to increase revenues from user charges. This instrument is much more varied than the tax, less fiscally efficient, but used all over the world. At the same time, just like the tax, it is associated with a group of characteristics that determine its impact. Among the most important objectives related to the introduction of user charges ensuring economic efficiency, financial stability and fair valuation of services are mentioned. Efficiency is understood in terms of allocation, i.e. payments that link the use of the service and an obligation to pay, limit excessive demand, so that resources can be used in other areas. Financial stability is associated with the generation of additional revenues, which can be explained, among others, by the Leviathan theory (Buchanan \& Brennan, 1980), according to which the public authorities will use all opportunities to increase public revenues. Fair valuation refers to the coverage of marginal social cost of the service. The combination of these three features, with particular emphasis on the first one, leads to the specific impact of charges, i.e. reducing unit costs.

This phenomenon is explained by the fact that the users/consumers, when paying for a service, are directly interested in the fact that the expenditure is low. It is understood by subsequent transfer of expenditures on user charges. In reality, therefore, there are two coupled effects - the impact of the user charges on the amount of unit expenditure and the impact of the amount of expenditure on the amount of user charges. While in the first case we can speak about the behavioural effect, in the second case, it is the effect of strictly financial importance. 


\section{Literature review}

There are two very important theorems in public finance that might be applied to reaction of citizens to user charges implementation. These are Lindahl (1958) prices and the Wicksell principle (Blankart \& Fasten, 2011). Lindahl prices aim to mimic market for public goods (where there is no market). According to this theory, taxpayers should be charged for a use of public services in accordance with their willingness to pay. Wicksell's theorem indicates the relationship between the amount of particular goods or services supplied by the public sector and the amount of fees and taxes that residents must pay for these goods and services. Wicksell and Lindahl presented models which show that if the decisions on public expenditure and its financing are taken at the same time and on the basis of unanimity (or quasi-unanimity) then between these two variables appears perfectly accurate and valid relationship.

This implies that the most important, financial feature of charges is the amount and method of determining it, and the interrelationships between service charges and expenditures to finance these services. Denek (2007) shows that the most frequently tackled aspect of the revenue autonomy, in proportion to total own source revenues, and therefore the charges for services, is covering the current expenditure and undertaking investment projects. As indicated by Holtz-Eakin, Newey, and Rosen (1989), the importance of such links was discussed by both economists and politicians.

An important observation from the point of view of the article's aim was made by Von Furstenberg, Green, and Jeong (1985). They formulated three hypotheses about the relationship between tax revenues and public expenditure:

- revenues change at the same time as expenditures,

- revenues change before taxes,

- expenditures change before taxes.

The extension of the concept of taxes to all public levies and taking into account the public nature of these payments, and the nature of charges (direct link with the feedback provision from the public entity), and thus also a certain legislative path associated with the determination of charges, indicates that in the Polish case, the second hypothesis is closest to the reality. This theorem is denied, however, by the results of research conducted on the panel of 50 US states, which show that the expenditures adapt, inter alia, to short-term changes in taxes and other sources of funding (Westerlund, Mahdavi, \& Firoozi, 2011). However, from a theoretical point of view, the amount of expenditures associated with the provision of services by public entities will be determined by market factors, taking into account a certain amount of user charge, which may be compared to one of the methods for determining the level of prices for products and services (Keegan, Moriarty, Duncan, \& Paliwoda, 1995). The level of user charges might also be influenced by economic characteristics such as income. Studies conducted in the Norwegian municipalities show that (Aaberge \& Langørgen, 2006): 
- user charges for kindergarten increase with family income, and decrease with municipal revenues,

- user charges for elderly and disabled care increase with household income.

User charges as a source of revenue have different characteristics when compared with taxes. The essential feature of the charges is flexibility in shaping their level. Feld, Kirchgässner, and Schaltegger (2003) indicate that while tax revenues cannot be flexibly formed, among others, due to tax competition, in the case of user charges for public services, this limitation is much less important. In most cases the local government units will decide on the amount of the user charges, taking into account the possible restrictions resulting from the law and the possibility of their payment by users.

Previous research on dependence of the user charges and expenditures for selected public services justify this approach. Among the most important one can find the following:

- Bierhanzl and Downing (1998) emphasize that a higher level of revenues from user charges for services in relation to expenditure for the service results in lower expenditure,

- Borge and Rattsø (2005), in a study on municipal services, have shown that the increase in the share of user charges in expenditures by $10 \mathrm{pp}$ reduces costs by $5-8 \%$,

- Swianiewicz and Łukomska (2011) indicate statistically significant correlation between the share of user charges paid by parents and income, education and population in Polish local government,

- Sun and Jung (2012) showed, with regard to the connection between disposal of sewage and parks in American cities, that greater reliance on user charges to finance these services leads to a reduction in government expenditures,

- Będzieszak (2015) in his study showed that correlation between user charges for services per capita and expenditure on these services per capita in large Polish cities in 2012 is $0.6810-0.9315$, and in the case of kindergartens 0.1958 .

\section{Local framework of the funding of kindergartens}

According to the Polish law, municipalities are responsible for establishing public kindergartens. This also applies to large cities. ${ }^{1}$ These units are also required to subsidize non-public kindergartens. If non-public kindergartens meet the requirements of public kindergartens and meet additional conditions, they receive the grant for each pupil in the amount equal to the planned current expenditure per one pupil in

\footnotetext{
1 They perform tasks of both municipalities and counties (supra-local level of LG). Usually they are large local government units, more important than municipalities.
} 
kindergartens run by the municipality, less user charges for pre-school education and for the board, constituting the budget revenues. In other situations, the grant will be equal to $75 \%$ of the amount indicated above.

Public kindergartens are currently financed from three main sources: user charges, grants from the state budget and other revenues of municipalities, and grants from the state budget are the most important. This is a result of the reform carried out in 2011, when the grants firstly appeared in the municipal budgets, with the aim to finance current tasks in the field of pre-school education. The second source of funding for public kindergartens are user charges (they were the most important until the introduction of the grants). What is worth emphasizing, however, is the fact that since the introduction of the grants, revenues from charges have not decreased significantly, which means that cities subsidy other own-source revenues (of general purpose, e.g. local taxes) with grants. The third, and the most diversified source are other own-source revenues of municipality.

Revenues that supply kindergartens can be collected in two different funds: the budget and separate account of own-source revenues. Kindergartens operate as budgetary units and can therefore generate revenues, e.g. from user charges for services or property lease. Under current law, those revenues cannot be directly used to finance kindergartens' expenditures, but kindergartens are required to pay them into the bank account of the city. It does not change the fact, however, that in terms of accounting, the revenues can be considered as a source of financing for kindergartens. The grants received from the state budget constitute the second source. Its level is fixed per student. Revenues supply the city budget from which the money is transferred to kindergartens.

Additionally, in Poland, public educational institutions, depending on the decision of a municipality, can create so-called accounts of own-source revenues, which are separated funds, supplied with specified sources under the current resolution, and can be used for current needs of these institutions (excluding salaries). Sources of revenues in these accounts, in the case of kindergartens, are mainly user charges.

The funds are earmarked, compulsory, and their revenues collection may be separated, which may fund defined expenditures (both sources of revenues and task are determined in the resolution of the municipal council). Revenues collected on those accounts do not supply the municipal budget, as is the case with ordinary own-source revenues, and can be used directly by the kindergartens. In the research period, sources of those revenues were user charges, fees, lease and rent, inheritances, bequests and donations. However, neither the charges nor grants alter the fact that public kindergartens are generally financed by other own-source revenues in approx. two-thirds. The structure of revenues is presented in Table 1. 
Pobrane z czasopisma Annales H - Oeconomia http://oeconomia.annales.umcs.pl Data: 26/04/2023 16:01:26

Table 1. Structure of revenues of kindergartens in large Polish cities (PLN)

\begin{tabular}{|l|l|r|r|r|r|r|r|r|}
\hline \multicolumn{2}{|c|}{ Item } & \multicolumn{1}{|c|}{2012} & \multicolumn{1}{c|}{2013} & \multicolumn{1}{c}{2014} & 2015 & \multicolumn{1}{c|}{2016} & \multicolumn{1}{c}{2017} & 2018 \\
\hline \multirow{2}{*}{ Budget } & own-source revenues & 300,385 & 264,990 & 200,817 & 227,827 & 75,148 & 67,519 & 76,208 \\
\cline { 2 - 9 } & grants & 42,334 & 202,273 & 541,226 & 551,681 & 559,346 & 494,767 & 521,769 \\
\hline Separate own-source revenues & 634,027 & 633,893 & 609,563 & 582,584 & 590,794 & 590,628 & 603,113 \\
\hline \multicolumn{2}{|l|}{ Total } & 976,777 & 976,611 & $1,076,825$ & $1,324,627$ & $1,370,301$ & $1,225,122$ & $1,165,399$ \\
\hline
\end{tabular}

Source: Author's own study.

User charges consist of three main parts: services going beyond the scope of free-of-charge activities (the rate is calculated per hour), for food and for extracurricular activities. The hourly user charges are usually in the range of PLN 1-3. The user charges collected on the accounts of own revenues are usually payments for meals for children and documents.

In 2011, a new system of financing kindergartens was introduced, according to which municipalities receive a grant for basic tasks of a kindergarten. The law has determined that the amount of subsidy on these tasks will be increased according to the schedule included in the amendment to an act on the education system. The year 2013 was therefore only a temporary period in which a higher level of subsidy per student was achieved. It should be noted, however, that the grant is only one of several sources of financing kindergartens. In addition, user charges for services and other revenues are collected. Currently, the subsidy is the most important revenues achieved in connection with the pre-school education. It constitutes almost $60 \%$ of all revenues of kindergartens. It should be noted, however, that there are two additional features of financing public kindergartens. Firstly, the introduction of grants had a very specific impact on other revenues, i.e. it was substituted only in part. In other words, the introduction of the grant did not result in the resignation of the charges or their part. In the first year, the grant payments fell by $15 \%$, in the second - by $25 \%$, but in the third, they began to rise again. The second feature is directly connected with this fact. Regardless of the introduction of grants, the main source of funding for kindergartens remained general own-source revenues (collected by municipalities and not by kindergartens). Revenues collected by the kindergarten, including grants, allow for the financing of only approx. 37\% of expenditure (see Table 3), which means that the remaining part comes from local taxes. Therefore, collecting user charges allows cities to maintain a higher level of "self-financing". Apart from the absolute values, this also means that the grant can cover approx. $15.8 \%$ of the average expenditure per pupil (see Table 2 ). 
Pobrane z czasopisma Annales H - Oeconomia http://oeconomia.annales.umcs.pl Data: 26/04/2023 16:01:26

IS THERE A LINK BETWEEN USER CHARGES AND EXPENDITURES ON PUBLIC KINDERGARTENS...

Table 2. Structure of kindergartens' operational revenues and expenditures, 2012-2018

\begin{tabular}{|l|r|r|r|r|r|r|r|}
\hline \multicolumn{1}{|c|}{ Item } & \multicolumn{1}{c|}{2012} & \multicolumn{1}{c|}{2013} & \multicolumn{1}{c|}{2014} & \multicolumn{1}{c|}{2015} & \multicolumn{1}{c|}{2016} & \multicolumn{1}{c|}{2017} & 2018 \\
\hline \multirow{2}{*}{ User charges } & 642,829 & 583,858 & 508,538 & 533,504 & 242,025 & 246,680 & 252,892 \\
\cline { 2 - 8 } & $65.8 \%$ & $54.2 \%$ & $38.4 \%$ & $38.9 \%$ & $19.8 \%$ & $21.2 \%$ & $20.6 \%$ \\
\hline \multirow{2}{*}{ Grants } & 42,334 & 202,273 & 541,226 & 551,681 & 559,346 & 494,767 & 521,769 \\
\hline \multirow{2}{*}{ Other revenues } & 291,448 & $18.8 \%$ & $40.9 \%$ & $40.3 \%$ & $45.7 \%$ & $42.5 \%$ & $42.6 \%$ \\
\cline { 2 - 8 } & $29.8 \%$ & 290,694 & 274,863 & 285,116 & 423,751 & 423,952 & 451,194 \\
\hline Total revenues & 976,611 & $1,076,825$ & $1,324,627$ & $1,370,301$ & $1,225,122$ & $1,165,399$ & $1,225,855$ \\
\hline $\begin{array}{l}\text { Total operating } \\
\text { expenditures }\end{array}$ & $2,568,409$ & $2,632,361$ & $2,731,638$ & $2,716,401$ & $2,814,530$ & $3,010,396$ & $3,300,677$ \\
\hline
\end{tabular}

Source: Author's own study.

\section{Research methodology}

In order to conduct the research, a general hypothesis has been defined: the level of user charges for services affects the level of expenditure on these services. In order to verify it, two specific hypotheses have been defined: 1 . A higher share of user charges for kindergartens in expenditure leads to a lower level of expenditure, i.e. a higher degree of pre-funding charges leads to savings in expenditure; 2. A higher level of expenditure on kindergarten leads to higher user charges for kindergartens, i.e. part of the increased expenditure is shifted to the payers.

The survey is based on the assumption that there is a significant correlation between the amount of user charges and expenditures for services financed by these charges. The general model and the expected direction of the relationship have the following form:

user charges $=f$ (expenditure, population, wages, local revenues)

and similarly:

expenditures $=f($ rates, population, wages, local revenues)

Besides the relationship between user charges and expenditures, additional variables for verifying other effects related to charges have been introduced. The variable describing the number of inhabitants is to determine the scale effect, i.e. a decrease in unit user charges and unit expenditures as a result of delivering of the service to a larger population.

The models are as follows:

$u c_{i t}=\alpha_{1} \times \exp _{i t}+\alpha_{2} \times r e v_{i t}+\alpha_{3} \times$ pop $_{i t}+\alpha_{4} \times s a l_{i t}+\alpha_{5} \times$ scholar $_{i t}+$ error 
$\exp _{i t}=\alpha_{1} \times$ share $_{i t}+\alpha_{2} \times$ rev $_{i t}+\alpha_{3} \times$ pop $_{i t}+\alpha_{4} \times$ sal $_{i t}+\alpha_{5} \times$ scholar $_{i t}+$ error

The research is conducted on a panel of 65 large Polish cities in the years 20122018. The sources of financial data are budget reports of the cities and in case of non-financial data - the Central Statistical Office.

The variables are:

$u c$ - user charges per pupil $\left(\frac{\text { user charges }_{i t}}{\text { number of pupilsit }}\right)$

exp - operating expenditure (excl. grants) per pupil ( $\left.\frac{\text { operating expenditure (excl.grants })_{i t}}{\text { number of pupils }}\right)$

share - share of operating expenditure (excl. grants) financed with user charges

$\left(\frac{\text { user charges }_{\text {it }}}{\text { operating expenditure (excl.grants) }}\right)$

rev - own source revenues per capita $\left(\frac{\text { operating own source revenues }_{i t}}{\text { number of inhabitants }}\right)$

pop - population

sal - yearly salary

scholar - number of pupils per one teacher

The results of estimation have been presented in Table 3. An assessment has been conducted on a panel of 65 large Polish cities in the years 2012-2018 using WLS, fixed/random effects in panel data analysis. Summary statistics, correlation matrix and variables dynamics has been shown in the annex.

\section{Results}

The most important conclusion from the estimation are coefficients for the exp variable in the first model and the share variable for the second model. In the first case, whatever method is used, the exp variable is important, it is highly significant. The coefficient is approx. $0.1-0.25$ which should be interpreted as an increase in user charges per student by PLN $0.10-0.25$ due to increased expenditure per student by PLN 1. It is assumed, therefore, that the rise of user charges is affected by an increase in expenditures, which can be justified in the principles of operating of kindergartens - an essential part of their expenditures constitute remuneration and utility charges, resulting in a constant, slight increase in expenditures. This also means that the $10-25 \%$ increase in expenditure is shifted to payers, namely the parents. The share variable is statistically significant. The values of the coefficients are similar. When interpreting these coefficients it should be noted that the increase in the share of user charges in expenditures by $10 \mathrm{pp}$ causes a decrease in expenditure by $2.5-5.0 \%$. However, given the correctness of estimations, the conclusion that the user charge is actually an instrument resulting in savings can be drawn. In particular, the second model is important in this case because it shows that increasing the share of user charges as a source of financing kindergartens leads to reduced expenditures and, 
Pobrane z czasopisma Annales $\mathrm{H}$ - Oeconomia http://oeconomia.annales.umcs.pl Data: 26/04/2023 16:01:26

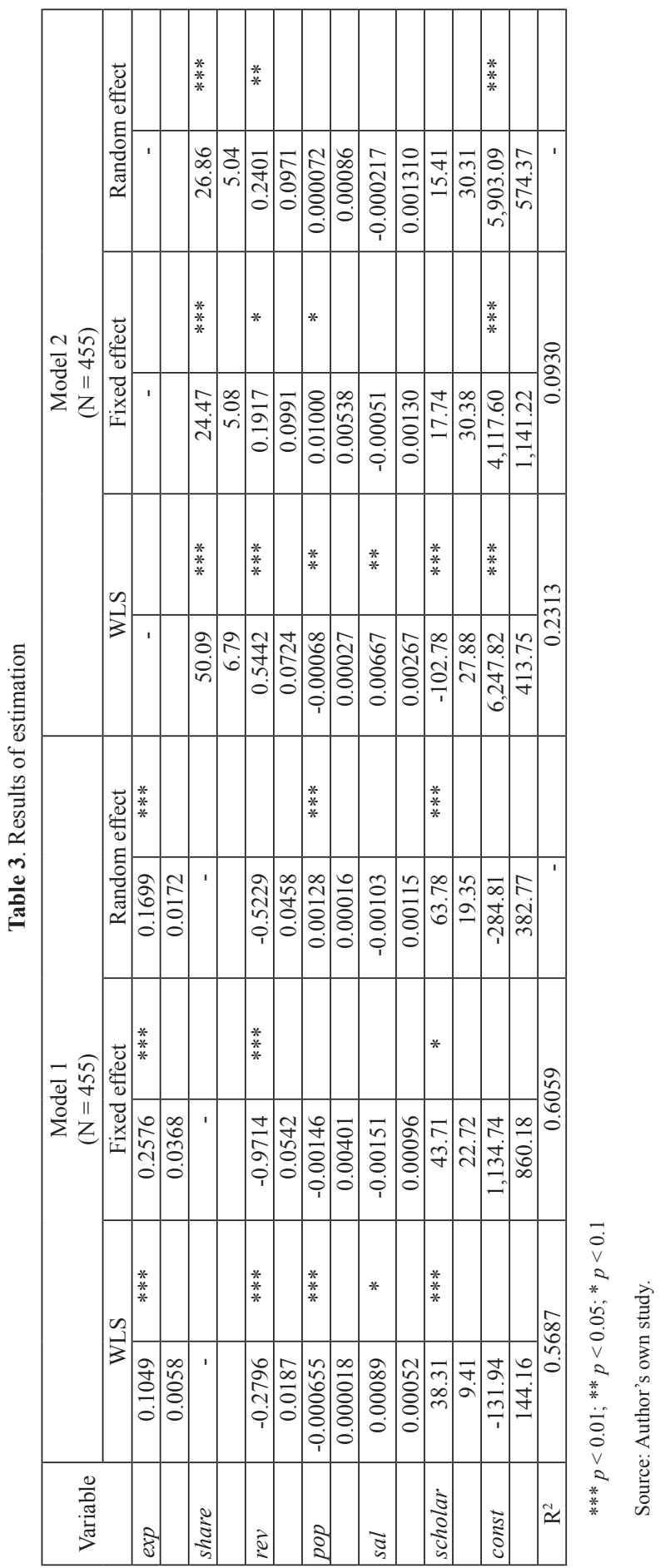


therefore, the introduction of user charges is an instrument to increase the efficiency of funding kindergartens in Poland.

It is also important to analyse the impact of the current own-source revenues per capita (rev) on the level of user charges, and in particular on the level of expenditures, operating own source revenues per capita (rev). In the first model, the variable has a negative direction, indicating that the higher the revenues the higher the revenues from user charges $(u c)$ and in the second, a positive direction indicated that the higher the revenues the higher the expenditures on kindergarten $(\exp )$. In the first case, an interpretation may not be clear. User charges for kindergarten are also the operating own-source revenues and, therefore, increased revenues from user charges result in an increased total amount of revenues. At the same time, the cities with higher own-source revenues per capita are characterized by higher revenues from user charges per student. For this reason, an interpretation of the meaning of the rev variable is more important for the second model. According to its design, the higher own source revenues per capita lead to higher expenditure per student. It is very reasonable, given the fact that kindergartens in Poland are financed from three sources: user charges, grants and other own-source revenues, e.g. taxes. The consequence of this is that the richer cities, with their own-source revenues, can spend more money to finance kindergartens, providing a higher standard of service. In addition, they are not forced to increase their spending on the kindergartens.

\section{Conclusions}

The aim of this article was to point out the link between user charges and expenditures on the example of public kindergartens in Poland. The rationale behind the aim is that implementation of user charges for public service results in efficient use of resources but also, as pointed out by Borge and Rattsø (2005), an increase in expenditures is borne by consumers. The first relation derives from the idea that consumers when faced with the duty to pay for a service, have interest in efficient use of expenditures, while the second correlation is a result of interest of local authority.

The empirical analysis is based on a panel data set for large Polish cities in the years 2012-2018. The estimates indicate that about $10-25 \%$ of an expenditure increase is borne by consumers and it refers to higher user charge. Moreover, user charge financing has a significant negative effect on the unit cost. An increase in the share of user charges in expenditures by $10 \mathrm{pp}$ causes a decrease in expenditure by $2.5-5.0 \%$. Additionally, an important conclusion from the analysis is that the cities used grant from the central budget effectively, i.e. without expenditure growth, and with the reduction of user charges. 


\section{References}

Aaberge, R., \& Langørgen, A. (2006). Measuring the benefits from public services: The effects of local government spending on the distribution of income in Norway. Review of Income and Wealth, 52(1), 61-83.

Będzieszak, M. (2015). Dochody z opłat za usługi samorządowe a poziom wydatków w miastach na prawach powiatów. Zarządzanie Publiczne, 2(30), 151-163.

Bierhanzl, E.J., \& Downing, P.B. (1998). User charges and bureaucratic inefficiency. Atlantic Economic Journal, 26(2), 175-189.

Blankart, C., \& Fasten, E.R. (2011). Knut Wicksell's principle of just taxation revisited. In: V. Caspari (ed.), The Evolution of Economic Theory. Essays in Honour of Bertram Schefold (pp. 132-141). London: Routledge.

Borge, L.E., \& Rattsø, J. (2005). The relationships between costs and user charges: The case of a Norwegian utility service. FinanzArchiv: Public Finance Analysis, 61(1), 98-119.

Buchanan, J.M., \& Brennan, G. (1980). The Collected Works of James M. Buchanan. Vol. 9: The Power to Tax: Analytical Foundations of a Fiscal Constitution. Indianapolis: Liberty Fund.

Denek, E. (2007). Dyskusyjne problemy dostosowania dochodów do zadań samorządu terytorialnego. In: K. Piotrowska-Marczak, K. Kietlińska (red.), Harmonizacja finansów publicznych w skali narodowej i europejskiej (pp. 423-431). Warszawa: Difin.

Feld, L.P., Kirchgässner, G., \& Schaltegger, C.A. (2010). Decentralized taxation and the size of government: Evidence from Swiss state and local governments. Southern Economic Journal, 77(1), 27-48.

Von Furstenberg, G.M., Green, R.J, Jeong, J.-H. (1985). Have taxes led government expenditures? The United States as a test case. Journal of Public Policy, 5(3), 321-348.

Holtz-Eakin, D., Newey, W., \& Rosen, H.S. (1989). The Revenues-Expenditures Nexus: Evidence from Local Government Data. International Economic Review, 30(2), 415-429.

Keegan, W.J., Moriarty, S.E., Duncan, T.R., \& Paliwoda, S.J. (1995). Marketing. Scarborough: Prentice Hall. Lindahl, E. (1958). Just taxation - a positive solution. In: R. Musgrave, A. Peacock (eds.), Classics in the Theory of Public Finance (pp. 168-176). UK: Palgrave Macmillan.

Sun, R., \& Jung, C. (2012). Does user-charge financing reduce expenditure levels for the charge-financed services? The American Review of Public Administration, 42(2), 170-185.

Swianiewicz, Ł., \& Łukomska, J. (2011). Finansowanie przedszkoli z różnych źródet. Warszawa: ORE.

Westerlund, J., Mahdavi, S., \& Firoozi, F. (2011). The tax-spending nexus: Evidence from a panel of US state-local governments. Economic Modelling, 28(3), 885-890.

\section{Annex}

Table 1. Summary statistics

\begin{tabular}{|l|r|r|r|r|r|}
\hline Variable & Mean & Median & \multicolumn{1}{c|}{ SD } & \multicolumn{1}{c|}{ Min } & Max \\
\hline uc & 480 & 326 & 511 & 0 & 2310 \\
\hline $\exp$ & 6940 & 7000 & 1850 & 2310 & 12100 \\
\hline share & 6.78 & 5.28 & 6.53 & 0.00 & 28.6 \\
\hline pop & 192000 & 113000 & 249000 & 36300 & 1770000 \\
\hline sal & 47800 & 46800 & 16600 & 4110 & 146000 \\
\hline rev & 2730 & 2540 & 812 & 1460 & 6670 \\
\hline scholar & 13.5 & 12.5 & 1.45 & 9.67 & 17.1 \\
\hline
\end{tabular}

Source: Author's own study. 
Pobrane z czasopisma Annales $\mathrm{H}$ - Oeconomia http://oeconomia.annales.umcs.pl

Data: 26/04/2023 16:01:26

MARCIN BĘDZIESZAK

Table 2. Correlation matrix

\begin{tabular}{|c|c|c|c|c|c|c|c|}
\hline$u c$ & $\exp$ & share & pop & sal & rev & scholar & \\
\hline \multirow[t]{7}{*}{1.0000} & 0.3583 & 0.9296 & 0.0661 & 0.0101 & -0.1012 & 0.0778 & $u c$ \\
\hline & 1.0000 & 0.0815 & 0.0480 & 0.1765 & 0.2349 & -0.1643 & exp \\
\hline & & 1.0000 & 0.0591 & -0.0290 & -0.1811 & 0.1538 & share \\
\hline & & & 1.0000 & 0.1404 & 0.6457 & -0.2534 & pop \\
\hline & & & & 1.0000 & 0.2450 & -0.0309 & sal \\
\hline & & & & & 1.0000 & -0.3687 & rev \\
\hline & & & & & & 1.0000 & scholar \\
\hline
\end{tabular}

Source: Author's own study.

Table 3. Means of variables

\begin{tabular}{|l|r|r|r|r|r|r|r|}
\hline Variable & \multicolumn{1}{c|}{2012} & \multicolumn{1}{c|}{2013} & \multicolumn{1}{c}{2014} & \multicolumn{1}{c|}{2015} & 2016 & \multicolumn{1}{c|}{2017} & 2018 \\
\hline uc & 1033 & 840 & 610 & 632 & 79 & 75 & 92 \\
\hline $\exp$ & 7162 & 6920 & 7038 & 7010 & 6764 & 6691 & 6995 \\
\hline share & 14.36 & 12.01 & 8.42 & 8.82 & 1.24 & 1.20 & 1.38 \\
\hline pop & 193466 & 192880 & 192542 & 192377 & 192177 & 192115 & 191920 \\
\hline sal & 44957 & 46333 & 47881 & 50199 & 52125 & 53780 & 39200 \\
\hline rev & 2318 & 2431 & 2632 & 2792 & 2878 & 2948 & 3087 \\
\hline scholar & 13.8 & 13.9 & 13.7 & 13.7 & 13.4 & 13.4 & 12.8 \\
\hline
\end{tabular}

Source: Author's own study. 